\begin{tabular}{c|c|c|}
\hline \hline & MARINE ECOLOGY PROGRESS SERIES \\
Vol. 276: 263-268, 2004 & Mar Ecol Prog Ser & Published August 2 \\
\hline \hline
\end{tabular}

\title{
Attraction of settlement-stage coral reef fishes to reef noise
}

\author{
S. D. Simpson ${ }^{1,5, *}$, M. G. Meekan ${ }^{2}$, R. D. McCauley ${ }^{3}$, A. Jeffs ${ }^{4}$ \\ ${ }^{1}$ Department of Biology, University of York, PO Box 373, York YO10 5YW, UK \\ ${ }^{2}$ Australian Institute of Marine Science, PO Box 40197, Casuarina, Darwin, Northern Territory 8010, Australia \\ ${ }^{3}$ Centre for Marine Science and Technology, Curtin University, GPO Box U 1987, Perth, Western Australia 6845, Australia \\ ${ }^{4}$ National Institute of Water and Atmospheric Research, PO Box 109-695, Newmarket, Auckland, New Zealand \\ ${ }^{5}$ Present address: School of Biological Sciences, University of Edinburgh, Kings Buildings, Edinburgh EH9 3JT, UK
}

\begin{abstract}
We compared catches of settlement-stage reef fishes in light traps attached to underwater speakers playing reef sounds with those of silent traps during a summer recruitment season at Lizard Island, Great Barrier Reef, Australia. Of the total 40191 reef fishes we collected, significantly more $(67 \%$; Wilcoxon and Binomial tests: $\mathrm{p}<0.001)$ appeared in the traps with broadcast reef noise. Traps deployed with speakers consistently caught a greater diversity of species (Wilcoxon test: $\mathrm{p}<0.001$, total 81 vs 68 ) than did silent traps. This study provides a clear demonstration that the settlement-stages of a broad range of families of coral reef fishes are attracted to reef sounds.
\end{abstract}

KEY WORDS: Coral reef fishes · Orientation · Sound · Cues · Settlement · Larvae · Light traps Resale or republication not permitted without written consent of the publisher

\section{INTRODUCTION}

How settlement-stage coral reef fishes navigate from the plankton to suitable reef habitats is poorly understood, although we know that some larvae are capable of locating and returning to their natal reefs (Jones et al. 1999, Swearer et al. 1999). Many potential navigation cues exist (see reviews in Montgomery et al. 2001, Kingsford et al. 2002, and Myrberg \& Fuiman 2002), but evidence to date supports only 2: chemicals and sounds. While chemical signals can influence settlement of reef fishes at small (10s to $100 \mathrm{~s}$ of metres) spatial scales (Sweatman 1988, Danilowicz 1996, Arvedlund et al. 1999), they are only available downstream of reefs and in areas of high current flow, so may only be of value to larvae that are strong swimmers (Armsworth 2000).

In contrast, in water sounds propagate irrespective of current direction over long distances with little attenuation (Rogers \& Cox 1988). Furthermore, coral reefs produce high levels of biological sound in the range 0.4 to $4 \mathrm{kHz}$ (Cato 1978), which is generated by organisms such as shrimps and fishes, and commonly reaches peak levels around dusk. Reef sounds are also lunar (around the new moon) and seasonally (spring and summer) cyclic (McCauley \& Cato 2000). Intriguingly, these patterns mirror equivalent temporal cycles in settlement of reef fishes (Doherty \& Williams 1988, Kingsford 2001).

Despite the great potential for sound to act as a cue for orientation at settlement, there is only limited experimental support for its use by the larvae of coral reef fishes during the settlement process. Inferential evidence was provided by Leis et al. (1996) and Stobutzki \& Bellwood (1998), who found, respectively, that settlement-stage fish swam away from reefs during the daytime and toward reefs at night irrespective of current. More recently, recorded reef sounds, but not artificial noises, were shown by Leis et al. (2002) to directly influence the daytime swimming behaviour of the settlement-stage larvae of the coral reef damselfish Chromis atripectoralis. Tolimieri et al. (2004) provide further evidence that pomacentrids not only respond to pre-recorded reef noise, but that they are able to determine the direction of the source, resolving a theoretical $180^{\circ}$ ambiguity along the axis of direction of the sound source (Montgomery et al. 2001). The enhancement of light-trap catches using recorded reef sounds was first 
demonstrated for a temperate reef fish, a tripterygiid blenny, in northern New Zealand (Tolimieri et al. 2000). Using a similar approach, Leis et al. (2003) provide evidence that some coral reef fishes show a response to recorded reef noise. However, it remains to be clarified whether attraction to sound is a widespread and general response among the larvae of coral reef fishes.

Here, we address this issue using light traps with and without a sound source broadcasting reef noise in the waters adjacent to Lizard Island, Great Barrier Reef (GBR), Australia. Previous work at this locality (Doherty 1987, Milicich 1988, Milicich \& Doherty 1994) has shown that light traps collect late-stage larvae from many families of reef fishes, often in great numbers (1000s per hour of fishing; Milicich 1988). This diversity and abundance allowed our study to examine the response to sound in a broad range of reef taxa.

\section{MATERIALS AND METHODS}

Sound treatment. The recording we used was a $4 \mathrm{~min}$ loop of the dusk chorus of biological noise recorded in the reef habitat at a mid-shelf reef on the GBR (Feather Reef, $17^{\circ} 32.28^{\prime} \mathrm{S}, 1^{\circ} 6^{\circ} 21.36^{\prime} \mathrm{E}$ ) during the new-moon phase. The recording was made using a calibrated Clevite CH17 hydrophone, a RANRL preamplifier (40 dB gain) and a Sony TCD-D7 digital tape deck. The spectral shape of the broadcast signal was similar to the recorded signal. For accurate level analysis the spectral content of the signal was analysed with a Hewlett Packard 3582-A 0-25 kHz spectral analyser, with the white noise and hydrophone sensitivity used to calibrate the signal.

Response of fishes to reef noise. Our study targeted 3 summer new-moon periods at Lizard Island $\left(14^{\circ} 40^{\prime} \mathrm{S}, 145^{\circ} 28^{\prime} \mathrm{E}\right)$, which is when the majority of reef fish settlement occurs (Milicich 1988, Meekan et al. 1993), from November 2001 to January 2002. We used permanent moorings anchored in 10 to $15 \mathrm{~m}$ depth of water over sand at 3 sites approximately $500 \mathrm{~m}$ offshore (2 in front of the Marine Station to the SW of the island, and 1 at Coconut Beach to the SE). To minimise site noise effects, each site was surveyed by divers to ensure there were no reefs in the vicinity. To avoid site effects, trap deployment alternated between the sites in front of the marine station (540 m apart) each night, except in January, when due to prevailing weather conditions some traps were deployed at the Coconut Beach site.

We used a modern light-trap design (Stobutzki \& Bellwood 1997, see Meekan et al. 2001 their Fig. 1). Our sound system consisted of a waterproof barrel containing a $12 \mathrm{~V}$ marine battery, $70 \mathrm{~W}$ amplifier, and a portable CD player. The sound was transmitted through an underwater speaker (UW-30, frequency response 0.1 to $10 \mathrm{kHz}$, University Sound, Buchanan; broadband source level set at $104 \mathrm{~dB}$ re $1 \mu \mathrm{Pa}$ at $1 \mathrm{~m}$ ) set $1 \mathrm{~m}$ below the water surface next to the light trap. To another (paired) trap we attached a similar, but empty, rig to monitor potential effects on catches of attraction by fishes to floating objects.

Within each site, pairs of light traps (silent and with broadcast reef sound) were deployed $180 \mathrm{~m}$ apart. This was far enough to prevent any overlap of light, which from in situ attenuation measurements, travels less than $50 \mathrm{~m}$ from light traps in clear water (Simpson 1999). Similarly, the speaker broadcasting reef noise would not be detectable above ambient noise within $50 \mathrm{~m}$ of the silent trap (cylindrical model of sound propagation; ambient levels: $82 \mathrm{~dB}$ re $1 \mu \mathrm{Pa}$ over the bandwidth of $20 \mathrm{~Hz}$ to $10 \mathrm{kHz}, \mathrm{R}$. McCauley unpubl. data). Therefore, we believe $180 \mathrm{~m}$ was the optimal distance to ensure that the traps were close enough to be sampling from the same assemblage of larval fishes without interfering in the operation of adjacent traps. The sound treatment was alternated between moorings within a site on successive nights. Traps were deployed before dusk and catches retrieved the following morning for a total of 37 nights. Reef fishes collected from the traps were preserved in ethanol, identified (in most cases to species) and counted.

Shapiro-Wilk analyses showed that data sets were not normally distributed (e.g. total catches: $\mathrm{W}=$ 0.39934, $\mathrm{p}<0.00001, \mathrm{n}=37$ ). For this reason, data were analysed using 2 approaches. Firstly, pairs of traps (1 silent, 1 with broadcast reef noise) were treated as replicate samples and analysed using the non-parametric Wilcoxon matched-pairs test (Sokal \& Rohlf 1995). This approach makes no assumptions about the behavioural interactions of the fishes. Secondly, the total numbers of fishes collected by each treatment were analysed using binomial probabilities (Sokal \& Rohlf 1995). This analysis offers greater statistical power, but assumes that all fishes were acting independently in their choice of trap, so that the behaviour of a fish was not influenced by other individuals nearby.

\section{RESULTS}

\section{Sound treatment}

The sounds recorded from Feather Reef were similar to evening chorus recordings from elsewhere on the GBR including Lizard Island (McCauley \& Cato 2000, McCauley 2001, Cato \& McCauley 2002). The noise consisted of a chorus of pops made by nocturnal fishes (intense choruses with a spectral peak over the 


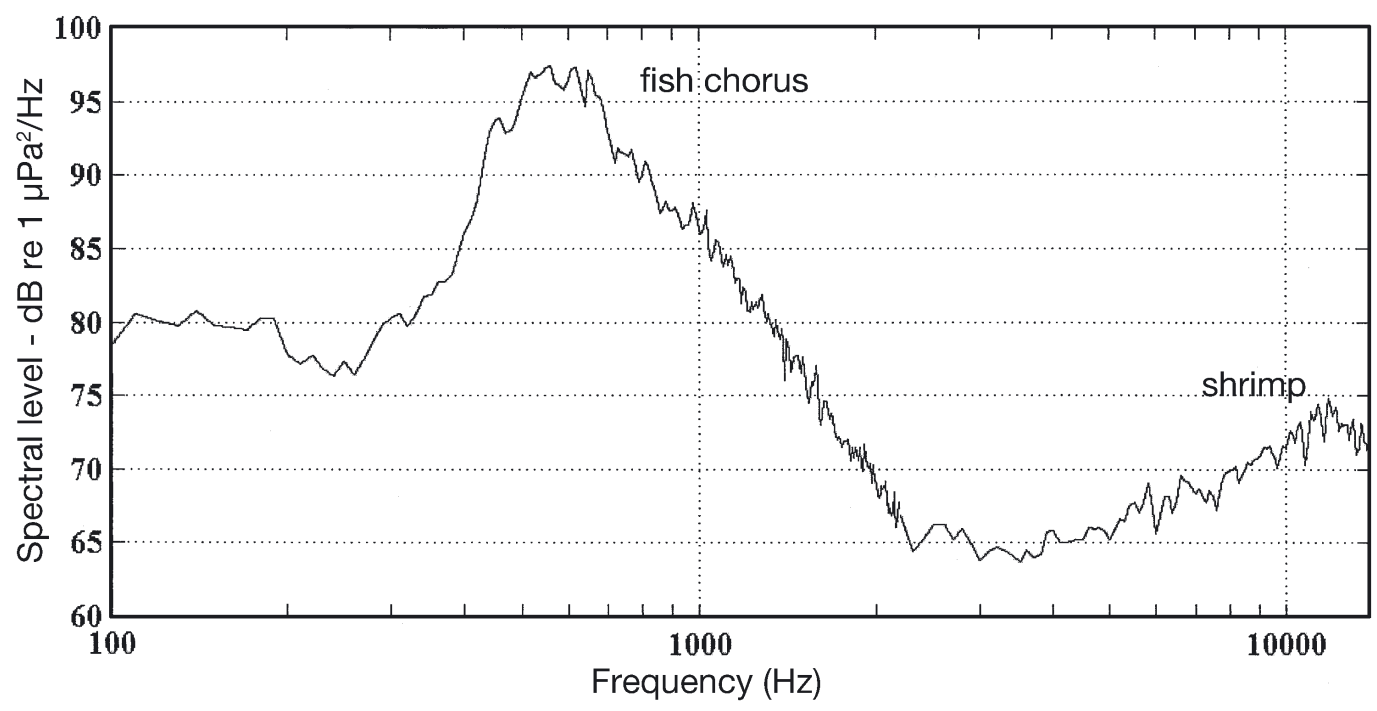

Fig. 1. Spectral content of biological sound broadcast from speakers near light traps at Lizard Island

frequency range 600 to $800 \mathrm{~Hz}$ ) overlaid on a lower level higher frequency (2.5 to $200+\mathrm{kHz}$ ) background crackle produced by snapping shrimps over the bandwidth of the recording equipment (Fig. 1).

\section{Response of fishes to reef noise}

A total of 44 pairs of traps were deployed during the study, although light-unit failure eliminated 7 paired comparisons. The remaining 37 paired samples (November: 16; December: 11; January: 10) collected 40191 settlement-stage reef fish from 90 species and 20 families, with the majority collected in December (November: 3477; December: 35869; January: 845). In total, $67.0 \%$ (26944) of the reef fishes were collected by light traps deployed with sound speakers. Removal from the data set of the results for one night (16 December) when $50.7 \%$ of the total number of reef fishes was collected did not affect this result and increased the catch of traps with broadcast reef noise to $70.4 \%$ of the total number of reef fishes caught.

Reef fishes from 20 families were collected in this study. The majority of individuals $(89.3 \%)$ were pomacentrids. Only 3 other families each exceeded $1 \%$ of the catch (apogonids, 6.2\%; syngnathids, $1.3 \%$; nemipterids, $1.3 \%$ ). Wilcoxon matched-pairs tests showed that the total number of reef fishes $(p<0.001)$, total number of species $(\mathrm{p}<0.001)$ and families $(\mathrm{p}<0.05)$ were greater in traps deployed with speakers than in silent traps each night.

Despite the great range in abundances of families of reef fishes in the catches, a consistent pattern was seen with an average of $62.6 \%$ of individuals from each family being collected in traps deployed with speakers (Fig. 2, Table 1). However, Wilcoxon matched-pairs analyses of these differences were only significant where total catches were very large (e.g. pomacentrids). In contrast, binomial probability analyses of the total catches for each family showed significantly greater catches in traps deployed with speakers than silent traps for all the 10 most abundant families (Table 1).

The pattern of greater catches in traps deployed with speakers was also consistent within families. Of the

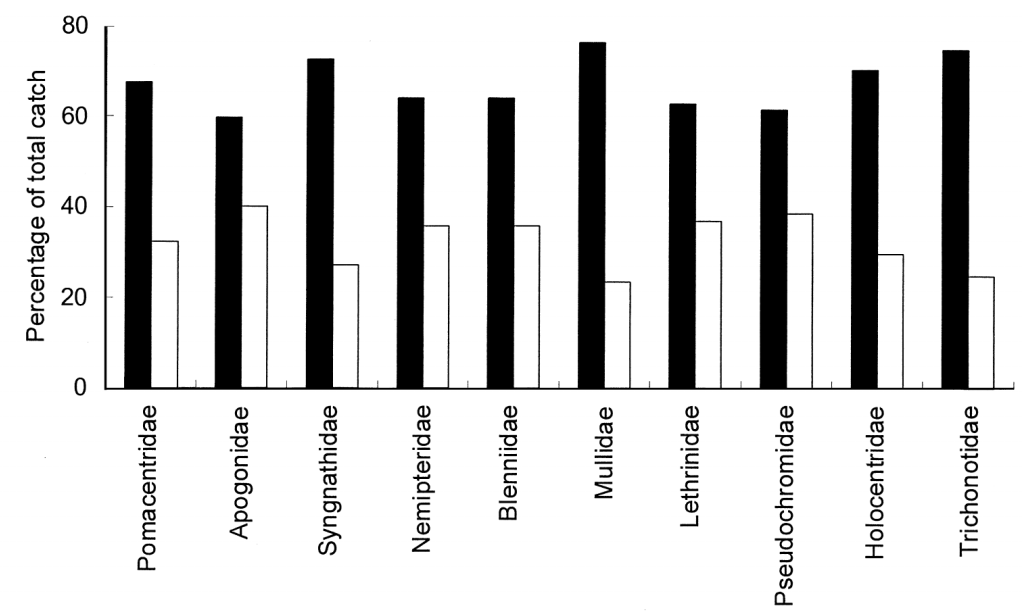

Fig. 2. Percentage catch of reef fishes in light traps deployed with speakers broadcasting reef noise (filled bars) and silent traps (open bars) during summer months at Lizard Island. Data are shown for those families for which more than 20 individuals were collected during the study 
31 species of pomacentrid from 10 genera collected by our study, 29 were collected in greater numbers in traps with broadcast reef noise (Table 2). Of the remaining 2 species, 1 unidentified pomacentrid appeared more often in silent traps than traps deployed with speakers, while Dascyllus trimaculatus was collected in equal numbers in both traps.

\section{DISCUSSION}

This study demonstrated that the ability to detect and respond to sound is widespread in the larvae of coral reef fishes. All families of reef fishes where more than 20 individuals were collected showed a strong response to sound cues. Approximately twice as many individuals of each family appeared in light traps deployed with speakers compared to silent traps. Our catches were composed of larvae that are representatives of many of the families that typify reef fish faunas, covering a diverse array of adult ecologies ranging from diurnal herbivores to nocturnal planktivores. Where comparisons were possible, we also found that the response to sound was consistent among individual species. Of the 31 species of pomacentrid from 10 genera collected, 29 displayed a preference for traps with broadcast reef noise (including Amblypomacentrus breviceps, a non-reef pomacentrid as an adult).
We do not know if the settlement-stage reef fishes collected by our light traps were attracted by the entire spectrum or only a small part of the sounds that we broadcast. The sounds we played were biological in origin and were largely composed of a background "crackle" produced by snapping shrimp overlaid by a series of pops, grunts and gurgles generated by nocturnal fishes, mostly holocentrids and apogonids (R. McCauley unpubl. data). Identification of the components of reef sounds that are particularly attractive to reef fish larvae and their sources will be the subject of future research.

The use of reef noise by fishes during settlement may have important implications for the management of reef systems. It seems possible that anthropogenic noises (e.g. turbines, ships) that overwhelm or drown out natural sounds attractive to larvae and fishing or pollution that targets components of the reef community responsible for producing sounds may have adverse effects on the replenishment of reef fish populations. Indeed some estimates indicate that anthropogenic noise increased the ambient noise in world's oceans by as much as $10 \mathrm{~dB}$ (1 full order of magnitude) between 1950 and 1975 (Jasny 1999). Conversely, if the reef noises that attract larvae can be identified, managers might be able to enhance recruitment and re-stocking in situations where overharvesting has impacted populations or new habitats have been created.

Table 1. Summary of catches of late-stage coral reef, reef-associated pelagic, and pelagic fishes in light traps deployed with (sound) and without (silent) speakers broadcasting reef noise at Lizard Island, Great Barrier Reef. Results of non-parametric Wilcoxon matched-pairs tests and binomial probability tests are shown (see 'Materials and methods' for details). Low catches prevented analysis of some taxa

\begin{tabular}{|c|c|c|c|c|c|c|}
\hline Family & Sound & Silent & Difference & Paired n & $\begin{array}{c}\text { Wilcoxon } \\
\text { p-value }\end{array}$ & $\begin{array}{c}\text { Binomial } \\
\text { p-value }\end{array}$ \\
\hline Pomacentridae & 24234 & 11654 & 12580 & 36 & 0.000 & 0.000 \\
\hline Apogonidae & 1478 & 997 & 481 & 31 & 0.123 & 0.000 \\
\hline Syngnathidae & 390 & 146 & 244 & 13 & 0.084 & 0.000 \\
\hline Nemipteridae & 337 & 188 & 149 & 23 & 0.178 & 0.000 \\
\hline Blenniidae & 183 & 102 & 81 & 17 & 0.187 & 0.000 \\
\hline Mullidae & 117 & 36 & 81 & 13 & 0.021 & 0.000 \\
\hline Lethrinidae & 83 & 49 & 34 & 15 & 0.064 & 0.003 \\
\hline Pseudochromidae & 51 & 32 & 19 & 9 & 0.889 & 0.036 \\
\hline Holocentridae & 19 & 8 & 11 & 10 & 0.019 & 0.032 \\
\hline Trichonotidae & 18 & 6 & 12 & 6 & 0.402 & 0.012 \\
\hline Labridae & 3 & 10 & -7 & 3 & 0.043 & 0.160 \\
\hline Tetradontidae & 9 & 4 & 5 & 7 & 0.214 & 0.125 \\
\hline Chaetodontidae & 8 & 3 & 5 & 9 & 0.068 & 0.024 \\
\hline Scorpaenidae & 1 & 7 & -6 & 4 & & \\
\hline Caesionidae & 3 & 3 & 0 & 6 & & \\
\hline Serranidae & 6 & & 6 & 5 & & \\
\hline Balistidae & 1 & 1 & 0 & 1 & & \\
\hline Siganidae & 2 & & 2 & 1 & & \\
\hline Acanthuridae & 1 & & 1 & 1 & & \\
\hline Microdesmidae & & 1 & -1 & 1 & & \\
\hline
\end{tabular}


Table 2. Summary of catches of late-stage pomacentrid fishes in light traps deployed with (sound) and without (silent) speakers broadcasting reef noise at Lizard Island, Great Barrier Reef. Results of non-parametric Wilcoxon matched-pairs and Binomial probability tests are shown (see 'Materials and methods' for details). Low catches prevented analysis of some species

\begin{tabular}{|c|c|c|c|c|c|c|}
\hline Species & Sound & Silent & Difference & Paired n & $\begin{array}{l}\text { Wilcoxon } \\
\text { p-value }\end{array}$ & $\begin{array}{l}\text { Binomial } \\
\text { p-value }\end{array}$ \\
\hline Abudefduf sexfasciatus & 28 & & 28 & 2 & 0.180 & 0.000 \\
\hline Abudefduf vaigiensis & 41 & 18 & 23 & 16 & 0.385 & 0.004 \\
\hline Amblypomacentrus breviceps & 260 & 132 & 128 & 16 & 0.002 & 0.000 \\
\hline Amphiprion sp. & 1 & & 1 & 1 & & \\
\hline Chromis atripectoralis/viridis & 1848 & 942 & 906 & 31 & 0.004 & 0.000 \\
\hline Chromis ternatensis & 6 & 5 & 1 & 6 & 0.783 & 1.000 \\
\hline Chrysiptera cyanea & 45 & 24 & 21 & 4 & 0.465 & 0.016 \\
\hline Chrysiptera flavipinnis & 272 & 34 & 238 & 4 & 0.197 & 0.000 \\
\hline Chrysiptera rollandi & 984 & 583 & 401 & 11 & 0.007 & 0.000 \\
\hline Chrysiptera talboti & 43 & 4 & 39 & 7 & 0.043 & 0.000 \\
\hline Dascyllus reticulatus & 22 & 15 & 7 & 12 & 0.344 & 0.034 \\
\hline Dascyllus trimaculatus & 1 & 1 & 0 & 2 & & \\
\hline Dascyllus aruanus & 27 & 14 & 13 & 8 & 0.028 & 0.061 \\
\hline Dascyllus sp. & 8 & & 8 & 6 & 0.020 & 0.008 \\
\hline Dischistodus perspicillatus & 235 & 45 & 190 & 11 & 0.021 & 0.000 \\
\hline Neopomacentrus azysron & 1014 & 411 & 603 & 15 & 0.040 & 0.000 \\
\hline Neopomacentrus cyanomos & 1330 & 501 & 829 & 20 & 0.002 & 0.000 \\
\hline Pomacentrus amboinensis & 5648 & 2469 & 3179 & 22 & 0.002 & 0.000 \\
\hline Pomacentrus bankanensis & 131 & 111 & 20 & 3 & 1.000 & 0.222 \\
\hline Pomacentrus brachialis & 2844 & 1475 & 1369 & 21 & 0.000 & 0.000 \\
\hline Pomacentrus coelestis & 1045 & 679 & 366 & 23 & 0.000 & 0.000 \\
\hline Pomacentrus lepidogenys & 1149 & 488 & 661 & 23 & 0.000 & 0.000 \\
\hline Pomacentrus moluccensis & 782 & 410 & 372 & 20 & 0.008 & 0.000 \\
\hline $\begin{array}{l}\text { Pomacentrus nagasakiensis/ } \\
\text { chrysurus }\end{array}$ & 2957 & 1479 & 1478 & 28 & 0.000 & 0.000 \\
\hline Pomacentrus sp. a & 671 & 486 & 185 & 14 & 0.046 & 0.000 \\
\hline Pomacentrus sp. b & 1711 & 584 & 1127 & 24 & 0.002 & 0.000 \\
\hline Pomacentrus sp. c & 550 & 208 & 342 & 7 & 0.018 & 0.000 \\
\hline Pomacentrus sp. d & 181 & 116 & 65 & 5 & 0.893 & 0.000 \\
\hline Pomacentrus sp. e & 68 & 173 & -105 & 9 & 0.013 & 0.000 \\
\hline Pomacentrus wardi & 329 & 247 & 82 & 11 & 0.373 & 0.000 \\
\hline Pristotis jerdoni & 3 & & 3 & 2 & 0.180 & 0.250 \\
\hline
\end{tabular}

Acknowledgements. We thank the staff at the Lizard Island Research Station, M. McCormick for aid with identification of reef fish larvae, C. Dudgeon, V. Messmer, N. Tolimieri, O. Hain and J. Montgomery for assistance in the field, C. Dytham for statistical advice and J. Leis and anonymous reviewers for comments that improved drafts of the manuscript. This work was supported by a Natural Environment Research Council postgraduate fellowship (to S.D.S.), the Australian Institute of Marine Science (to M.G.M.), and the Marsden Fund (to A.J.).

\section{LITERATURE CITED}

Armsworth PR (2000) Modelling the swimming response of late stage larval reef fish to different stimuli. Mar Ecol Prog Ser 195:231-247

Arvedlund M, McCormick MI, Fautin DG, Bildsoe M (1999) Host recognition and possible imprinting in the anemonefish Amphiprion melanopus (Pisces: Pomacentridae). Mar Ecol Prog Ser 188:207-218

Cato DH (1978) Marine biological choruses observed in tropical waters near Australia. J Acoust Soc Am 64:736-743

Cato DH, McCauley RD (2002) Australian research in ambient sea noise. Acoust Aust 30:1-13
Danilowicz BS (1996) Choice of coral species by naïve and field-caught damselfish. Copeia 1996 735-739

Doherty PJ (1987) Light traps: selective but useful devices for quantifying the distributions and abundances of larval fishes. Bull Mar Sci 41:423-431

Doherty PJ, Williams DM (1988) The replenishment of coral reef fish populations. Oceanogr Mar Biol Annu Rev 26: $487-551$

Jasny M (1999) Sounding the depths; supertankers, sonar and the rise of undersea noise. Natural Resources Defense Council, New York

Jones GP, Milicich MJ, Emslie MJ, Lunow C (1999) Selfrecruitment in a coral reef fish population. Nature 402: 802-804

Kingsford MJ (2001) Diel patterns of abundance of presettlement reef fishes and pelagic larvae on a coral reef. Mar Biol 138:853-867

Kingsford MJ, Leis JM, Shanks A, Lindeman KC, Morgan SG, Pineda J (2002) Sensory environments, larval abilities and local self- recruitment. Bull Mar Sci 70:309-340

Leis JM, Sweatman HPA, Reader SE (1996) What the pelagic stages of coral reef fishes are doing out in blue water: daytime field observations of larval behavioural capabilities. Mar Freshw Res 47:401-411 
Leis JM, Carson-Ewart BM, Cato DH (2002) Sound detection in situ by the larvae of a coral-reef damselfish (Pomacentridae). Mar Ecol Prog Ser 232:259-268

Leis JM, Carson-Ewart BM, Hay AC, Cato DH (2003) Coralreef sounds enable nocturnal navigation by some reef-fish larvae in some places at some times. J Fish Biol 63: 724-737

McCauley RD (2001) Biological sea noise in northern Australia: patterns of fish calling. PhD thesis, James Cook University, Townsville

McCauley RD, Cato DH (2000) Patterns of fish calling in a nearshore environment in the Great Barrier Reef. Phil Trans R Soc Lond B 355:1289-1293

Meekan MG, Milicich MJ, Doherty PJ (1993) Larval production drives temporal patterns of larval supply and recruitment of a coral reef damselfish. Mar Ecol Prog Ser 93:217-225

Meekan MG, Wilson SG, Halford A, Retzel A (2001) A comparison of catches of fishes and invertebrates by two light trap designs, in tropical NW Australia. Mar Biol 139:373-381

Milicich MJ (1988) The distribution and abundance of presettlement fish in the nearshore waters of Lizard Island. Proc 6th Int Coral Reef Symp 2:785-788

Milicich MJ, Doherty PJ (1994) Larval supply of coral reef fish populations: magnitude and synchrony of replenishment to Lizard Island, Great Barrier Reef. Mar Ecol Prog Ser 110:121-134

Montgomery JC, Tolimieri N, Haine OS (2001) Active habitat selection by pre-settlement reef fishes. Fish Fish 2:261-277

Myrberg AA, Fuiman, LA (2002) The sensory world of coral reef fishes. In: Sale PF (ed) Coral reef fishes: Dynamics and diversity in a complex ecosystem. Elsevier Science,

Editorial responsibility: Otto Kinne (Editor),

Oldendorf/Luhe, Germany
New York, p 123-148

Rogers PH, Cox M (1988) Underwater sound as a biological stimulus. In: Atema J, Fay RR, Popper AN, Travolga WN (eds) Sensory biology of aquatic animals Springer-Verlag, New York, p 131-149

Simpson SD (1999) Developments in the light trapping of recruitment-stage reef fishes, and the subsequent reduction in settlement mortality of light-trap caught Stegastes leucostictus through their culture in captivity MRes thesis, University of York

Sokal RR, Rohlf FJ (1995) Biometry. The principles and practice of statistics in biological research, 3rd edn. WH Freeman, New York

Stobutzki IC, Bellwood DR (1997) Sustained swimming abilities of the late pelagic stages of coral reef fishes. Mar Ecol Prog Ser 149:35-41

Stobutzki IC, Bellwood DR (1998) Nocturnal orientation to reefs by late pelagic stage coral reef fishes. Coral Reefs 17: 103-110

Swearer SE, Caselle JE, Lea DW, Warner RR (1999) Larval retention and recruitment in an island population of a coral-reef fish. Nature 402:799-802

Sweatman H (1988) Field evidence that settling coral reef fish larvae detect resident fishes using dissolved chemical cues. J Exp Mar Biol Ecol 124:163-174

Tolimieri N, Jeffs A, Montgomery JC (2000) Ambient sound as a cue for navigation by the pelagic larvae of reef fishes. Mar Ecol Prog Ser 207:219-224

Tolimieri N, Haine O, Jeffs A, McCauley R, Montgomery J (2004) Directional orientation of pomacentrid larvae to ambient reef sound. Coral Reefs (in press)

Submitted: February 21, 2003; Accepted: February 17, 2004 Proofs received from author(s): July 20, 2004 